\title{
Meta
}

Journal des traducteurs

Translators' Journal

\section{Historical, Theoretical and Terminological Perspectives of Translation in Africa}

\section{Charles Atanganna Nama}

Volume 38, numéro 3, septembre 1993

URI : https://id.erudit.org/iderudit/003693ar

DOI : https://doi.org/10.7202/003693ar

Aller au sommaire du numéro

Éditeur(s)

Les Presses de l'Université de Montréal

ISSN

0026-0452 (imprimé)

1492-1421 (numérique)

Découvrir la revue

Citer cet article

Atanganna Nama, C. (1993). Historical, Theoretical and Terminological Perspectives of Translation in Africa. Meta, 38(3), 414-425.

https://doi.org/10.7202/003693ar

\section{Résumé de l'article}

Dans cet article, nous proposons d'étudier les perspectives historique, théorique et terminologique de la traduction en Afrique. Jusqu'à présent, aucune étude sérieuse n'a été publiée sur l'histoire de la traduction et de l'interprétation en Afrique, un tel travail étant très ambitieux et d'une envergure considérable. L'Afrique est une véritable "tour de Babel" et compte des siècles d'histoire, c'est pourquoi un projet d'une telle ampleur serait plus facilement réalisable en procédant pays par pays. Un texte aussi important sur l'histoire de la traduction et de l'interprétation en Afrique aurait l'avantage d'être une source inestimable de références pour les étudiants, les enseignants, les chercheurs et les centres de recherche. 


\title{
HISTORICAL, THEORETICAL AND TERMINOLOGICAL PERSPECTIVES OF TRANSLATION IN AFRICA ${ }^{1}$
}

\author{
Charles Atangana Nama \\ University of Buea, Buea, Cameroun
}

\begin{abstract}
Résumé
Dans cet article, nous proposons d'étudier les perspectives historique, théorique et terminologique de la traduction en Afrique. Iusqu'à présent, aucune étude sérieuse n'a été publiée sur l'histoire de la traduction et de l'interprétation en Afrique, un tel travail étant très ambitieux et d'une envergure considérable. L'Afrique est une véritable «tour de Babel» et compte des siècles d'histoire, c'est pourquoi un projet d'une telle ampleur serait plus facilement réalisable en procédant pays par pays. Un texte aussi important sur l'histoire de la traduction et de l'interprétation en Afrique aurait l'avantage d'être une source inestimable de références pour les étudiants, les enseignants, les chercheurs et les centres de recherche.
\end{abstract}

A definitive text on the history of translation and interpretation in Africa is yet to be written because of the enormity and ambitious scope of the project. Considering the fact that Africa is a "babel of tongues" and its history is centuries old, such a major project might be feasible if handled on a country by country basis. In the final analysis, a major text on the history of translation and interpretation in Africa would be an invaluable source of reference for students, scholars and research centres. In this paper, I intend to analyze translation in Africa from historical, theoretical and terminological perspectives.

Such a major project is hampered by several factors including the absence of written accounts on the subject. This problem is aggravated by the fact that most of the history of Africa prior to the age of imperialism is unwritten. As if these are not enough, the myth that translation and especially interpretation in Africa began with the advent of imperialism seems to have been embraced and concretized even in intellectual circles. However, there is some degree of authenticity to the fact that translation as it is practised today in European languages, that is, "the transfer of meaning from one linguistic system into another," to borrow George Steiner's definition in After Babel: Aspects of Language and Translation did not exist in Africa prior to the advent of imperialism. However, if we also acknowledge George Steiner's view that translation of verbal signs falls into three categories amongst which is transmutation, that is, "an intersemiotic process during which verbal signs are interpreted by means of non-verbal sign-systems-pictorial gestural, and mathematical," (p. 250), then we can infer that some form of translation took place in Africa before the advent of imperialism. This concept is further reinforced in light of J. C. Catford's definitions and classifications in A Linguistic Theory of Translation, in which he notes inter alia that "phonological" and "graphological" translation are found in different societies. In fact, the history of translation, especially the early part, confirms this hypothesis. Consequently, considering the graphic nature of different kinds of writings in pre-colonial Africa, it is imperative that the history of translation in Africa be cognizant of Catford's definitions in order to enhance research in this area. The assertion that these kinds of translation took place in several African countries prior to the 
encounter with the West has been well documented by several eminent historians among them, Chancellor Williams in his monumental work, The Destruction of Black Civilization and Cheikh Anta Diop in The African Origin of Civilization.

In addition, based on concrete historical evidence, it has been amply documented that almost one thousand years before, African languages notably, Amharic in Ethiopia, hieroglyphics in Egypt were written. Most of these manuscripts deal with sacred and secular societies. Since these languages thrived in ancient Africa as Cheikh Anta Diop has documented in his works, it is fitting to infer that interlingual and intralingual types of translation and interpretation took place in ancient Africa. It would be interesting, particularly for a student of Ancient African history to coordinate a research team with a contemporary translator to trace the kinds of translation and interpretation patterns which took place in these pre-colonial societies. This kind of field work will entail a lot of travelling and extensive use of archives but it will contribute immensely to a comprehensive history of translation and interpretation in Africa.

The peculiar pictorial writing of Ancient Africa, particularly Egyptian, is succinctly discussed by Hallo and Simpson in The Ancient Near East who suggest that:

The language of the ancient Egyptians is written with a system of picture signs. A sign representing a consonant, a group of consonants, or the word for the object depicted, can also serve merely as a picture at the end of a group of consonants indicating the meaning or category of the word (for example, legs for a verb of motion...) The formal script, on which the pictures are usually recognizable, is called hieroglyphic. It was used for inscriptions on stone and carved or painted on wall surfaces...2

This kind of writing was prevalent in several African countries prior to the imperialist age. In actual fact, despite the advent of European languages in Africa, "pictorial languages" still flourish in the continent. Hallo and Simpson's observation cited above clearly indicates that this kind of artistic expression definitely had its own linguistic structures and systems. Engelbert Mveng underscores this point when he notes in L'Art et l'artisanat africains:

Il existe et il a toujours existé une histoire écrite : celle du langage symbolique des arts. L'Art nègre est une écriture... Le génie négro-africain transforme l'objet en signe, en symbole; ce signe ou ce symbole sont lisibles à l'ail initié. L'Art nègre crée donc un véritable langage écrit. Il est possible aujourd' hui de lire cette écriture... ${ }^{3}$

Father Mveng further indicates that this form of traditional writing is found in several African societies, notably among the Baluba and Bakuba of Zaire, the Ashanti, Akan, Baoulé and Adinkra of Ghana and the Ivory Coast and the Bamileke and Bamoun of Cameroon.

The history and culture of ancient, pre-colonial Africa resides in documents of this nature. In order to decipher the meanings of the texts, a special, scholarly kind of translation is required. In A Linguistic Theory of Translation Catford gives some clues on "graphological and phonological" translation. His guidelines might be appropriate but inadequate for the special kind of translations required by these ancient texts. Cheikh Anta Diop, Engelbert Mveng and some other researchers have started deciphering the meanings of these pictorial writings. Their methodology suggests not only a transfer of meaning from one linguistic system into another, but also an analytic, interpretative, elucidatory system of conveying ideas of texts in a given historical era. Given the significance of signs, symbols and meaning in current linguistic theories of translation, Mveng's and Diop's methods of translation and interpretation of graphological writings in precolonial Africa have unravelled a great deal of information concerning African societies. 
Consequently, this type of scholarly translation is inevitable in any serious study of the history of translation and interpretation in Africa.

Scientifically, material gleaned from the works of several indefatigable scholars indicate that the history of translation and interpretation in Africa can be divided into the following historical epochs: pre-colonial and contemporary. Most of the data for the precolonial era is not easily accessible. However, intensive research in archives and especially historical documents which captured traditional African societies such as works by William Bascom and Robert Farris Thompson shed a great deal of light in this area. In addition, pictorial writings of ancient societies are very useful in this context. Another invaluable source of information concerning the history of translation and especially interpretation in the traditional era is unquestionably oral historians whose validity and intellectual might have been scientifically proven. Interestingly, most of the information required for analysis is found in the major African epics such as Niane's Soundjiata, Thomas Mofolo's Chaka, Daniel Biebeyuk's Mindo Epic, John Pepper Clark's Ozidi Saga and Eno Belinga's l'Épopée camerounaise: Mvet ou l' homme bleu.

One of the major concepts which can be deduced and thus inform our appreciation of the historical significance and evolution of the translator/interpreter from pre-colonial to contemporary times is his esoteric role in society. Data from these texts indicate an alarming revelation. With the advent of imperialism, the Okyeame, as he was known in traditional Akan-Ghanaian society, has lost his status in the contemporary world. In actual fact, his status might never be the same again even though it can be argued that a handful of privileged contemporary translators and interpreters participate in presidential and international conferences. The contrast and downward trend of the translator/interpreter's role in evidenced by the pivotal function he played in ancient, pre-colonial Africa. In the following excerpt from the Malian epic Sounjiata: ou l'Épopée mandingue, Niane observe:

Si, aujourd' hui, le griot est réduit à tirer parti de son art musical ou même à travailler de ses mains pour vivre, il n'en a pas toujours été ainsi dans l'Afrique antique. Autrefois les griots étaient les Conseillers des rois, ils détenaient les constitutions des royaumes par le seul travail de la mémoire; chaque famille princière avait son griot préposé à la conservation de la tradition; c'est parmi les griots que les rois choisissaient les précepteurs de jeunes princes. Dans la société africaine bien hiérarchisée d'avant la colonisation, où chacun trouvait sa place, le griot nous apparait comme l'un des membres les plus importants de cette société car c'est lui qui à défaut d'archives, détenait les coutumes, les traditions et les principes de gouvernement des rois... 4

The privileged place of the Okyeame or griot in the royal courts was manifested in traditional African societies by the amount of political clout which he wielded. Even though, when the royal courts were in session he demonstrated his unquestionable proficiency in languages by interpreting simultaneously across two or more different African languages, his powers were evident beyond the courts. In this context, the translator/ interpreter in the traditional African world seems to have enjoyed a higher social standing than his counterpart in contemporary African societies because of the power, privileges and prerogatives which went with his office. On the other hand, the Okyeame or griot and his counterpart in the Western world share a common ground in their exceptional mastery of languages.

This diminishing role of the translator/interpreter in African societies was accentuated with the advent of Islamic and European imperialism. Unlike in the traditional society where he was revered, in the imperialist age he acted more or less as a guide, mediator and counselor to his colonial master. Interviews with a handful of interpreters 
who worked in the colonial era indicate that some of them were selected on the basis of their mastery of the territory, linguistic ability and stamina to endure long journeys. They were given crash courses in European languages and then sent to the field almost instantaneously. While in the eyes of the local population they seemed so powerful, and indeed some of them were, a majority discovered that once their exercises were over, they were either banished temporarily or relegated to the background and then called upon again whenever the need arose.

Today, the trappings of the job have been reduced to that of any other senior civil servant in his country's public service. The profession is lucrative primarily for a handful of interpreters who are opportuned to attend international conferences. During field work, it was discovered that a majority of professional translators feel that considering the demands of the job, they have not been given the status and position they deserve in society. Some even complained that even though they are among the ranks of top civil servants financially, their power and status can in no way be compared to that of a district officer.

The history of translation and interpretation in Africa must of necessity be cognizant of the colonial factor, that is, Arab and European. Such an exhaustive study is beyond the scope of this work. However, it must be viewed in terms of translation and interpretation in African languages, African languages into languages, and European languages into European languages. Furthermore, such a study would be more plausible if it were divided into geographical regions considering the different waves of imperialist expansionism which ravaged and ransacked the continent during different epochs in our turbulent history.

Linguistically, the wars of aggression perpetrated by colonialists evidently magnified the translator's problems across the continent especially if we consider the fact that language interference - vis- $\grave{a}$-vis indigenous African languages and foreign tongues created new kinds of languages.

In The True Interpreter: A History of Translation Theory and Practice in the West, Louis Kelly's observations are quite pertinent. He notes:

... Modern linguists, among them Roman Jakobson and J. C. Catford distinguish three types of translation: intralingual (rewording in the same language), interlingual (rewording in another language) and transmutation (rewording in another code altogether). 5

Because of the linguistic diversity of the African continent, coupled with the historical factors which have impinged on it, these three kinds of translation cited above took place and are still functioning in the continent. Throughout the continent, the following European languages are official languages: English, French, Spanish and Portuguese. The following classifications indicate the complexity of the linguistic situation in the continent and shed some light on the historical and seminal role of the translator and interpreter working across African languages, that is interlingually. R. Armstrong reminds us in A Study of West African Languages, that, for scholarly purposes, African languages were classified into specific "families."

In West Africa for example, the "Niger-Congo family," which includes over 400 languages, can be divided into the following sub-families:

I) The West Atlantic languages, spoken mainly in Senegal, the Gambia, Guinea Bissau, Guinea and Sierra Leone. They include mainly Wolof, Fula, Serer, Dyola, Temno, Kissi and Limba.

II) The Mande languages spoken in Guinea, Sierra Leone, Mali, Liberia, Northern Guinea Bissau, Côte d'Ivoire and Upper Volta (Burkina Faso). They include Soninke, Malinke, Bambara, Susu, Mende, Gio and Kpelle. 
III) The Gur language found in Mali, Upper Volta (Burkina Faso) Northern Ghana, Togo, Benin and Niger and including especially Senufo, Lobi, Dogon, Moore Dagomba, Mampnusi, Kakre and Bariba.

IV) The Kwa languages found in Liberia, Ivory Coast, Ghana, Togo, Benin, Nigeria and including mainly Kru, Baule, Tar, Ga, Ewe, Fon, Yomba, Edo, Nupe, Idoma, Ijo, and Efik.

V) The "Benue-Congo" languages, which include well over 78 languages more or less related to Bantu. 6

Besides Armstrong, other linguists among major Africanists such as Senghor have commented on the richness of African languages. In L'Esprit de la civilisation ou les lois de la culture négro africaine (1956) Senghor notes that:

The African languages are characterized first of all by the richness of their vocabulary. There are sometimes twenty different words for an object according to its form, weight, volume and colour, and as many for an action according to whether it is single or repeated, weakly or intensely performed, just beginning or coming to an end. In Fulani, nouns are divided into twenty-one genders which are not related to sex. The classification is based sometimes on the meaning of the words or the phonetic qualities and sometimes on the grammatical category to which they belong. Most significant in this respect is the verb. On the same root in Wolof can be constructed more than twenty verbs expressing different shades of meaning and at least as many derivative nouns... ${ }^{7}$

Senghor's remarks are tenable and applicable to quite a good number of African languages. Consequently, given their linguistic complexities in terms of syntax, lexicology, morphemes, phonemes, etc., it is evident that as intralingual and interlingual translations took place in several parts of the continent, given the commercial and political activities of the different societies, certain major translation problems confronted translators and interpreters. Among them we could mention textual equivalence, transmutation - in the hermeneutic sense as used by George Steiner.

In light of Senghor's discussion above, it is significant to add that the kinds of translation and interpretation prevalent in many African societies during the traditional era were complicated as a result of the meanings and equivalent terms in different languages.

A particular domain where these difficulties manifested themselves glaringly was the translation of proverbs, which, in the traditional world, were the prerogatives of the elders who were occasionally orators in their own right. In this context, no specific esoteric use of language was easily acceptable. In other words, it wasn't just a question of decoding and encoding ideas but also maintaining the stylistic elements of the proverb and in some cases its phonology. This kind of translation was not swept away by colonization. It still thrives in several parts of the continent and of course in Cameroon. I have witnessed a few occasional cases in some villages and it is imperative to add that the interpreter frequently assumes the role of an actor in the sense that he has to dramatize certain events when he cannot find their linguistic equivalents in his target language.

Recently, thanks to modern technology, Cameroon Television (CTV) recreated an interpretation scene in traditional society in one of its programmes, "Témoins de l" histoire" (November and December 1986). The event took place in the royal palace of the Lamido of Garoua in Northern Cameroon. A CTV journalist posed a question to a griot and it was interpreted from French into Fulfulde by another bilingual interpreter who made extensive use of his notebook and pen. After rendering the question in Fulfulde, the griot or traditional interpreter, relying on his memory, relayed the required information almost instantaneously. The setting as portrayed on the screen, modern technology notwithstanding, certainly evoked the interpretation scenes in traditional African society. What was particularly intriguing was the fact that there was consecutive, interlingual interpretation 
very similar to what is practised today by western-trained professionals. As mentioned earlier, this kind of interpretation still thrives in many parts of Africa. It should be emphasized that in some parts of Africa, for example among the Bafut of the North-West Province in Cameroon, most people can communicate with the king or Chief only through an interpreter. Royal interpreters in traditional African societies had to be initiated before communicating with the Chief or traditional ruler who, it was assumed, had divine powers.

In a recent television documentary entitled "The Africans," Ali Mazrui, the controversial Kenyan scholar and historian, tries to recapture what he appropriately describes as Africa's triple heritage, namely, Islamic, Christian and traditional Africa. Religious intervention in the African continent began around 800 A.D. when in their zeal to spread Jslam the Berbers of North Africa, waged jihads on several parts of North, West and East Africa. A few hundred years later, around 1365 and 1491, Europeans landed in Africa disguised as missionaries charged with the responsibility of spreading the gospel. These interventions had far reaching consequences for translation and interpretation in the African continent. In their zeal to spread the faith, language contact between Arabic, European languages and African languages was inevitable. Even though it took a long time for the Koran to be translated into African languages, it is evident that a reasonable degree of interpretation took place in North, West and East Africa in Arabic and African languages. Of increasing interest to the translator is the translation of these sacred Islamic and Christian texts into African languages. This king of translation still flourishes in Africa today especially if we take into consideration the plethora of evangelical denominations which have sprouted all over the continent. In this electronic age, a new wave of consecutive, live interpretation of religious material from European languages into African ones can be seen beaming on screens from Nairobi to Dakar. In fact, even jet set preachers like Oral Roberts and Son have indulged in this kind of media extravaganza in African countries. Of special note to the translator/interpreter is that two factors come into play here. Primo, use of the media to highlight interpretation into African languages for the masses and secundo, the confidence and fluency of the interpreters in rendering their messages in the target languages. Sometimes they are compelled to be theatrical.

The translation of religious material into African languages poses special problems for the translator. From a comparative perspective, Louis Kelly's observations in "Approaching the text" in The True Interpreter: A History of Translation Theory and Practice in the West is noteworthy. He observes that in translating the Hebrew Old Testament, St. Jerome employed a rabbi as informant. He adds: ... Two centuries afterwards, correspondence between Luther, Melanchthon and Spalation
shows that, although Luther took final responsibility for the German bible, an incredible
amount of consultation on theology, language and customs went on... All the members of
his company were noted biblical scholars and theologians... Another important variation
was that the texts from the companies underwent further revision from a revising panel
before publication, an example followed to this day. Modern biblical translation into "exotic"
languages shows a variant imported from linguistic field work. Nida (1961: 64) describes the
traditional team of biblical Scholars and Theologians, but adds to the team a native infor-
mant whose task is to check proposals for stylistic worth as a guide to the translator who has
had to work between two foreign languages...8

Given the linguistic variants of African languages and the multiplicity of meaning generally attached to specific words, it is therefore indispensable that revising and the services of a local informant be put at the services of the translator/interpreter. The cultural differences might need some clarifications especially if we take into account the differences between traditional African and Western religions. In addition, the astute 
translator in this area must be very knowledgeable in African traditional religions. In this regard, works by John Mbiti African Religions \& Philosophy and Idowu Traditional African Religions will be quite useful.

Nida and Taber inform us in The Theory and Practice of Translation that bible translating began in the third century B.C. and involved as many as 1393 languages by 1968. Given the colonial history of Africa and the extraordinary enthusiasm shown by missionaries to convert Africans, it is not amazing that translation of the bible into African languages began around the seventeenth century. By 1658, an African language, the Ge of the Ewes (inhabitants of present day Dahomey) was included in a major document, Doctriana Christiana, a handbook for missionary purposes. It was not much later, in the nineteenth century that a considerable amount of work was done in translating the Bible into African languages. Like St Jerome, St Augustine and other translators who were skilled in translating sacred texts, the following "missionary translators" can be credited with pioneering the work of biblical translation in Africa. They include among others J. F. Schon and S. W. Koealle. They started by studying African languages, specifically Housa, Igbo, Mende, Kanurai and Vai. Foremost among the early African "missionary translators" is Bishop Samuel Ajayi Crowther, a Nigerian who translated the Bible into Igbo and Yoruba (Nigerian languages). Substantial progress has been made in translating the Bible into at least 100 African languages. Eugene Nida himself has been quite active in these workshops, most recently, in Edea, Cameroon, working with the American Bible Society, translating the gospel into Cameroonian languages.

Another dimension of the history of translation and interpretation in Africa which needs special emphasis is the translation of written Literatures in the continent. From a comparative perspective, Louis Kelly in The True Interpreter: A History of Translation Theory and Practice in the West and George Steiner in After Babel: Aspects of Language and Translation underscore the pivotal function of literature in the evolution of translation theories and practice. Literature, Linguistics and Translation constitute an indivisible trinity in the analysis of any historical or theoretical aspects of translation and interpretation. What these three disciplines share in common is their reverence, the Written Word and its functional role in the creative process. In other words, the man of letters, the linguist and the translator are all active participants in the mechanics and linguistic acrobatics of the creative process. Kelly and Steiner confirm the thesis that the history of translation in the Western world is synonymous with that of literary history. Consequently, it is no accident that the pillars and principal architects of translation theory and history from Cicero-46Bc through St Jerome to Alexander Pope, Charles Baudelaire, Ezra Pound, Dryden to the present moment were and are mostly men of letters.

Ancient and contemporary African history also establish the same intriguing parallels between literature, translation and linguistics. A vast body of written African literatures thrived before the encounter with the West. In actual fact, Albert Gerard in African Language Literatures pays eloquent testimony to the fact that a vast quantity of translated texts, not only literary but also scientific, existed in Africa for centuries. Based on concrete historical evidence, it is an open secret that some parts of Africa had written Literatures before many parts of Western Europe. Centuries before Caesar led his Roman Legions to civilize Gaul (France), Celtic Britain and the Draidic German tribes of Vercingetorix in the 1st Century B.C., the African Nile Valley civilizations of Pharaohnic Egypt, Nubia, Kush, Meroe and present day Ethiopia had literate cultures. Consequently, any comprehensive study on the history of translation and interpretation in Africa which intends to underscore the significance of Literature and specifically the enormous contributions of men of letters to Translation theory and history must delve into ancient African literature as far back as 1st Century B.C. Even though this seems an uphill task, it is 
worth mentioning for research purposes, that some of these early texts were preserved and are available in major departments of African studies and Universities in Europe and North America.

Literature, like translation, is a linguistic event. African literature in European languages presents special problems for the African and non-African translator because of language contacts and interference and the cross-fertilization of African and European languages throughout the continent which have influenced different kinds of artistic expression from Cape Town to Cairo. Within the scope of this study, it is necessary to underscore the fact that literary translation in Africa is still a novelty but is governed by similar constraints which have influenced this special kind of translation. Hartman's remarks in Contrastive Textology: Comparative Discourse Analysis in Applied Linguistics concerning literary translation is noteworthy. He suggests:

... the study of literary texts, their production, transmission, critical evaluation and verbal art. The traditions, judgments and methods of literary theory must be respected when we try to account for the ways in which works of literary art cross linguistic and cultural boundaries... The task of the (literary) translator is to produce an equivalent text, typically for a reader who is not proficient enough to understand the text in the language of the original. Andre Lefevère's seven different types or "strategies" of literary translation: phonemic translation, literal translation, metrical translation, poetry into prose, rhymed translation, blank verse and free interpretation. ${ }^{9}$

Hartmann and Lefevère's salient observations are very pertinent to the relationship between literature and Translation in Africa. Lefevère's observations and classification would be extremely useful particularly in an African context, where the cultural imperative influences linguistic structures in all the major literary genres in oral and written African literatures.

Before delving into a detailed analysis of the interrelationships between "creative translation," literature and translation in Africa, it is useful to indicate that historically, a vast body of African Literature of Portuguese expression thrived in Africa in the nineteenth century. It is necessary to underscore this point because the general belief in academic circles is that the translation of African texts into European languages began in the 1960s with Achebe, Soyinka, Beti, Bebey, Ngugi and a host of other artists. Lusophone African literature comprising works produced in Angola, Mozambique, Guinea Bissau, Cape Verde, São Tome and Principé is of special significance in the development of literary translation in Africa. It can be analyzed from two perspectives, namely, the works produced in European languages and the African component which pioneered the creative impulse in African languages in Angola, for example such as those in Kimbundu and Umbundu. In Voices from an Empire: A History of Afro-Portuguese Literature, Russell Hamilton reminds us that when the Portuguese imperialists arrived in Africa in 1493, under the guidance of Diogo Cao they taught the Africans how to write. Their arrival is interesting from a translator's standpoint because of the kinds of writings which emerged from these areas. After a few educational institutions were established, a literary movement emerged known as the 1880 Group which founded a journal, $O$ Echo de Angola (The Echo of Angola). This journal is important in the historical development of translation and interpretation in Africa because if played a major role in publishing some of the earliest translated works from European into African languages, in this case, from Portuguese to Kimbundu, one of the main Angolan languages. $O$ Echo de Angola was a bilingual journal - Portuguese / Kimbundu.

The 1880 Group is also remarkable because it nurtured one of Africa's major colonial translators and terminologists, Joaquim Dias Cordeiro da Matta, a linguist, who published his collection of Kimbundu proverbs and riddles in Portuguese, Philosophia 
popular em proverbios angolanos (Popular Philosophy in Angolan Proverbs). Da Matta's pivotal role as a pioneer in the field is underscored by Russell Hamilton who notes in Voices from an Empire: A History of Afro-Portuguese Literature:

Cordeiro da Matta followed his collection of proverbs with a Kimbundu grammar and a Kimbundu-Portuguese dictionary in 1892 and 1893 respectively. Concerning the dictionary, Chatelain wrote in 1894 that it was the best Kimbundu word list to-date. Along with its efforts to preserve a Kimbundu heritage through folkloric and philological works, Cordeiro da Matta also attempted to record the glories of the past. He (Chatelain) and Cordeiro da Matta combined talents on several projects dealing with language and folklore... ${ }^{10}$

Cordeiro da Matta's scholarship confirms his pioneering role as a translator and terminologist in the history of translation in Africa during the colonial period. During a period when terminology is assumed to be a relatively new field in Africa, despite the fact that the Translation Unit at the United Nations has always encouraged its relevance to translation research, it might be gratifying to note that over a century ago, Cordeiro da Matta did some original work in this field. His Kimbundu-Portuguese dictionary, which Russel Hamilton describes as a "monument of scholarship," is a major contribution in this field similar to that made in Cameroon during the colonial era by Peter Makembe, Charles Atangana and Pierre Messi-Manga who published bilingual dictionaries in German-Ewondo. These terminologists undoubtedly contributed immensely to language and translation projects in the continent.

Translation of texts into African or European languages in the pre-independence era was pioneered by Mwalimu, Julius Nyerere (former President of Tanzania) who translated Shakespeare's Julius Caesar into Kiswahili. Nyerere's attempt was acclaimed in East Africa especially if we take into account the fact that, even though the continent of Africa still lacks an acceptable international vehicle of communication, in East Africa, approximately 100 million Africans in eight countries use Kiswahili. This, in effect, has several implications on translation studies in Africa. In fact, G. A. Mhina has published a book, The Place of Kiswahili in the Field of Translation. Mhina raises most of the major problems concerning the translation of African texts and the pivotal role that Kiswahili has played in the historical evolution of translation and interpretation in East Africa. It is evident from his study that the questions of formal and dynamic equivalence are major problems to the translator who works with Kiswahili given Senghor's germane observations about the multiplicity of meanings usually attached to specific words in African languages. Mhina's analyses also prove that most of the Western-oriented, linguistic-bound translation theories have certain flaws which in some cases are inapplicable. Their major weakness is the absence of socio-cultural factors which impinge on works produced by African artists. Kiswahili and other major East African languages such as Acholi in Uganda and Gikuyu in Kenya have become principal vehicles of communication. Several works, newspapers, etc., are produced in Kiswahili. The major Tanzanian poet Robert Shabaan's works, originally written in Kiswahili, have been translated into English. Similarly, Okot P'Bitek's, Song of Lawino, Song of Ocol, etc., were written in Acholi, and later translated into English, Spanish, Portuguese and French. The prominent Kenyan writer, Ngugi Wa Thiong'o wrote his last novel Devil on the Cross in Gikuyu and later translated it into English. It is evident from the works of these artists that translation is a major activity in East Africa.

Okot P'Bitek, the Ugandan writer, translator and terminologist, like Joaquim Dias Cordeiro da Matta of Angola, Eno Belinga of Cameroon, Wole Soyinka of Nigeria, and Ngugi Wa Thiong'o of Kenya, holds a special place in the history of translation and interpretation in Africa because of his spectacular contributions in translating from African 
into European languages. Bitek's methodology in translating his works from Acholi into English deserves special mention. His preface to a collection of poems entitled Horn of My Love is noteworthy. He remarks:

\begin{abstract}
Here is the poetry of the Acoli people: their lullabies and love songs, their satinical verses, their religious songs and chants, their war songs and funeral dirges... In Part One I have discussed briefly the different dances or occasions when the songs are sung. Part Two consists of the texts, both in the Acoli language and in English. It is important to stress that these are my own translations, and I believe that there can be other versions. It is for this reason that the vernacular had to be included, to give other translators and scholars the opportunity to criticize my translation and also to attempt their own. In Part Three I have thrown together several items ranging from analysis of the themes in Acoli dirges, the role of poets as historians, a description of the so-called "praise," and a rendering of the warriors' titles... 11
\end{abstract}

The distinctive, outstanding feature of Bitek's method of translation is that he adopts an aspect of what George Steiner calls the "hermeneutic model" in After Babel. Steiner notes that "the mechanics of translation are primarily explicative; they explicate or strictly speaking "explicitate and make graphic as much as they can of the semantic inherence of the original. Because explication is additive, because it does not merely restate the original unit but must create for it an illustrative context "translations are inflationary" (p. 160). Steiner's observation here is very pertinent to Bitek's translation of Acoli songs in Horn of My Love. Bitek's "explicative" method is evidenced by the fact that he creates "a graphic... illustrative" context for his songs. As he himself notes in the quotation cited above, he has analyzed specific themes, concepts, philosophies of Acoli society in order to make the translation of his poems more meaningful. This kind of socio-cultural approach or additional, valuable information to the translated text is not generally considered by linguistic-oriented theories of translation. It is his method of translation which makes his poems so comprehensible and the translated text becomes more appreciated than Clive Wake and John Reed's of Senghor's poetry.

Secondly, Bitek's expertise as a terminologist [he also published another book Mere Words - African Publishing House) has been very useful in his translation of difficult expressions which might have no equivalent in the target language - English. For example, instead of glossing over titles - of warriors and noble characters who are depicted in his poetry, he has added an analytical glossary of "warrior's titles" in order to facilitate the comprehension of his translated text. For example, Bwanga-moi is the title endowed on "One who throws only one spear and puts the enemy to flight" or Abel-moi, denoting "One who puts the enemy to flight."

It is evident that oral and written literatures have played a major role in the evolution of the history of translation and interpretation in Africa. Comparatively, the seminal role of literature in translation history and theory is outclassed only by that of religion in the discipline. It is thus no accident that any serious study of translation and interpretation in Africa must examine the functional role of oral and written literature. After all, all texts in the final analysis are literary. Even the most technical texts have to be rendered in a particular manner or style, addressed to a specific audience, specialists or government officials and are structured in a particular way. Their "meaning," of course, has to be conveyed in a special way.

Historically, it is erroneously assumed that translation and interpretation in African countries relating to economic matters and documents began in the $1960 \mathrm{~s}$ at the dawn of independence. As a matter of historical fact, it must be stated that as far back as 1365 when the first Europeans arrived in the (Ivory Coast) la Cote d'Ivoire, trading activities which took place certainly involved interpretation from one language into another. Trade in this context, should be examined from the following perspectives, a) between 
Africans, $b$ ) Africans and Arabs and c) Africans and Europeans. Fr. Mveng reminds us in his authoritative text, Histoire du Cameroun that even before the advent of Arab and European imperialism, a great deal of trade flourished among Africans. In all the three categories mentioned above, intralingual and interlingual translations and interpretation took place. Even though the levels of interpretation which took place were different and as such may not suscribe to the tenets which Seleskovitch mentions in l'Interprète dans les conférences internationales, it is evident that some form of interpretation took place. It is pertinent to add that to this day, this kind of interpretation still thrives between Africans of different linguistic persuasions during intertribal marriage ceremonies, land disputes and even the selling of produce.

When most African countries became independent in the 1960s, the demand for translators and interpreters assumed paramount importance. Interestingly in the postcolonial era, that is from 1960, the history of translation and interpretation in Africa has evolved in the following areas: African/European languages, and European into European languages. Foreign affairs, economic matters, religion, administrative and cultural domains are the main areas in which translation and interpretation have flourished.

Diplomatically, with the formation of the Organization of African Unity in 1962 under the aegis of Presidents Nkrumah and Toure of Ghana and Guinea respectively, the OAU was born after abortive attempts to form the Mali Federation. Due to the colonial legacy, foreign languages notably, English, French, Portuguese and Spanish were inherited, and became official languages in most African countries whereas Arabic was and is widely used in the Maghrebian countries of North Africa. Since, as George Steiner notes in After Babel, a historical study of translation and interpretation is a study of language and culture, in Africa this idea is quite pertinent. The choice of European languages as the main vehicles of communication in such a key African organization in the face of historical realities, is in essence, symptomatic of a kind of decay or political demise of the general African condition. This is significant if we take into account the fact that language is the translator's main instrument but, it is also as Jacques Derrida notes succinctly in $D e$ la grammatologie translated by Gayatri Spivak as Of Grammatology, quoting Duclos:

\begin{abstract}
... The language is the property of the people. Each derives its unity from the other. For if language has a body and a system, they inhere in the people assembled and "bodily united:" It is a people in a body that makes a language... A people is thus the absolute master of the spoken language, and it is an empire they possess unawares. To dispossess the people of their mastery of the language and thus of their self-mastery, one must suspend the spoken element in language. Writing is the very process of the dispersal of the peoples enslavement...12
\end{abstract}

Two factors need some rigorous analyses here concerning the historical evolution of translation and interpretation in Africa. Primo, in the midst of this august assembly of the $\mathrm{OAU}$, the translator/interpreter is viewed as a mediator, an intermediary who facilitates communication between Africans and participants who use different languages. This is, to all intents and purposes, no small feat. Secundo, however, being a political organization whose main objective is to achieve African unity, it is incongruous if not problematic that this unification of Africans aimed at articulating an African worldview, is done in foreign tongues. The Italian words traductore, traditore express the view that all translation is a betrayal of the original because "total translation" as defined by Catford is practically impossible. From a political standpoint, translation and interpretation of African questions in the most honourable assembly in the continent in foreign tongues then, is an act of linguistic and nationalistic betrayal. As Derrida's quotation cited above indicates, there is a "dispossession," a symbolic linguistic enslavement of an entire continent through this act of translation and interpretation which takes place at Addis Abada 
annually. Even though one hundred million Africans speak Swahili, it has not yet been accepted as a medium of communication for the continent. To paraphrase Derrida again, since language is the "property of the people," it would be most appropriate and desirable if an African language or African languages become the main languages for translation and interpretation at the OAU. It might be encouraging to note that at tribal meetings, African languages are the main means of communication.

With the advent of independence in 1960, a plethora of economic, international groupings were formed in the continent. The most prominent being ECOWAS which consists of sixteen African countries which use English and French as their working languages. Other organizations such as WARDA - West African Rice Development Authority, ECCAS - The ECOWAS of Central Africa, ISSA - International Social Security Association, etc., conduct several meetings annually where translation and interpretation activities play a vital role.

Translation and interpretation in Africa have contributed to contemporary theories in the field. These contributions have been articulated partially in Okyeame: A History of Translation: A Case Study of Cameroon.

As far as terminology is concerned, as mentioned earlier, African translators have contributed to its development. One of the most ambitious terminology banks in the continent is at the University of Dar es Salaam in Tanzania undertaken in conjunction with the National Swahili Council (Baraza la Kiswahili la Taifa). Researchers of this project are actively involved in the standardization of terminology especially in scientific and technical fields but also in grammar. Its findings are published in a journal Tafsiri Sanifu. In other parts of the continent, similar terminology banks are in their embryonic stages.

In conclusion, translation and interpretation in Africa have been an integral part of the people's lives for centuries. A few organizations such as the Nigerian Association of Translators and Interpreters (NATI) organize annual conferences to promote translation studies and research in the continent. Another excellent example of such an active organization is the Tanzania Organization of Translators (Chama cha watafsiri Tanzania - CHAWATA) ${ }^{13}$ founded in 1982 which is also promoting translation research in the continent.

\section{Notes}

1. This is an excerpt from a book in progress, Okyeame, A History of Translation and Interpretation in Africa: A Case Study of Cameroon (forthcoming).

2. Hallo and Simpson (1971): The Ancient Near East, New York, Harcourt Brace Jovanovich, p. 15.

3. Engelbert Mveng (1980): l'Art et l'artisanat africains, Yaoundé, Éditions Clé, p. 90.

4. Niane (1960): Sounjiata ou l'Épopée mandingue, Paris, Présence africaine, p.s.

5. Louis Kelly (1980): The True Interpreter: A History of Translation Theory and Practice in the West, New York, Columbia University Press, p. 86.

6. R. Armstrong (1967): A Study of West African Languages, Ibadan, Ibadan University Press.

7. Leopold Sedar Senghor (1956): "L'esprit de la civilisation ou les lois de la culture négro africaine," Présence africaine, June-November.

8. Louis Kelly (1980): The True Interpreter, New York, Columbia University Press, p. 86

9. R. R. K. Hartmann (1980): Contrastive Textology: Comparative Discourse Analysis in Applied Linguistics, Heidelberg, Julius Groos Verlag, pp. 62-63.

10. Russell Hamilton (1975): Voices from an Empire: A History of Afro-Portuguese Literature, Minneapolis, University of Minnesota Press, p. 15

11. Okot p'Bitek (1974): Horn of my Love, London, Heinemann, pp. ix-x.

12. Jacques Derrida (1976): Of Grammatology translated by Gayatri Splvak, Baltimore, John Hopkins University Press, p. 36.

13. Waalter Bgoya (1987): Babel: International Journal of Translation, ${ }^{\circ} 4$, vol. XXX III, pp. 224-231. 